UNIVERSIDADE DE SÃO PAULO

FACULDADE DE MEDICINA DE RIBEIRÃO PRETO

VINICIUS CESAR MOTERANI

Relação entre sobrevida pelo câncer de ovário e volume de cirurgias em hospitais do estado de São Paulo

Ribeirão Preto

2020 
VINICIUS CESAR MOTERANI

Relação entre sobrevida pelo câncer de ovário e volume de cirurgias em hospitais do estado de São Paulo

Dissertação apresentada à Faculdade de Medicina de Ribeirão Preto da Universidade de São Paulo, como requisito para a obtenção do Título de Mestre em Ciências Médicas.

Área de Concentração: Ginecologia e Obstetrícia.

Orientador: Prof. Dr. Francisco José Candido dos Reis

Ribeirão Preto

2020 
Autorizo a reprodução e divulgação total ou parcial deste trabalho, por qualquer meio convencional ou eletrônico, para fins de estudo e pesquisa, desde que citada a fonte.

\section{Moterani, Vinicius Cesar}

Relação entre sobrevida pelo câncer de ovário e volume de cirurgias em hospitais do estado de São Paulo / Vinicius Cesar Moterani. Orientador: Prof. Dr. Francisco José Candido dos Reis. - 2020. $41 \mathrm{f}$.

Dissertação (Mestrado) - Programa de Pós-Graduação em Ginecologia e Obstetrícia, Faculdade de Medicina de Ribeirão Preto, Universidade de São Paulo, Ribeirão Preto, 2020.

Orientador: Reis, Francisco José Candido dos.

Versão original

1. Câncer de ovário 2. Cirurgia 3. Epidemiologia 4. Sobrevida 
MOTERANI, V. C. Relação entre sobrevida pelo câncer de ovário e volume de cirurgias em hospitais do estado de São Paulo. 2020. 41 f. Dissertação (Mestrado) - Faculdade de Medicina de Ribeirão Preto, Universidade de São Paulo, 2020.

Aprovado em:

Banca Examinadora

Prof. Dr.

Instituição:

Julgamento:

Prof. Dr.

Instituição:

Julgamento:

Prof. Dr.

Instituição:

Julgamento:

Prof. Dr.

Instituição:

Julgamento:

Prof. Dr.

Instituição:

Julgamento: 


\section{AGRADECIMENTOS}

Ao meu orientador, Prof. Dr. Francisco José Cândido dos Reis, pelos conselhos e sugestões na elaboração deste trabalho.

A Fundação Oncocentro de São Paulo, pelo compartilhamento dos dados indispensáveis para realização do presente estudo.

A minha noiva, Larissa, pelo apoio e estímulo para a busca destas metas e objetivos.

Aos meus pais, Elaine e José Wilson, por desde o início terem me dado as condições para que eu trilhasse esse percurso e já na infância me ensinado a valorizar o estudo e o aprendizado.

Aos meus irmãos, Danielle e Nino, pelas alegrias que apenas a família pode proporcionar.

Ao meu amigo de toda uma vida, Luís, pela sua amizade e conselhos inestimáveis, especialmente nos momentos mais difíceis.

A todos os professores, colegas e funcionários do serviço de pós-graduação, que forneceram serviços importantíssimos para construção deste trabalho.

A Deus, princípio e fim de todas as minhas ações e Luz que me guia.

A todos que direta ou indiretamente contribuíram, sintam-se agradecidos.

O presente trabalho foi realizado com apoio da Coordenação de Aperfeiçoamento de Pessoal de Nível Superior - Brasil (CAPES) - Código de Financiamento 001. 


\section{RESUMO}

MOTERANI, V. C. Relação entre sobrevida pelo câncer de ovário e volume de cirurgias em hospitais do estado de São Paulo. 2020. 41 f. Dissertação (Mestrado) - Faculdade de Medicina de Ribeirão Preto, Universidade de São Paulo, 2020.

Introdução: $O$ câncer epitelial de ovário é uma doença altamente heterogênea. Cirurgia e quimioterapia são ambos componentes importantes do tratamento. Nós avaliamos neste estudo a importância do tipo de hospital na sobrevida global de pacientes portadoras de câncer epitelial ovariano. Objetivos: Nosso objetivo foi identificar se as características do hospital impactaram a sobrevida global do paciente. Nós consideramos tanto características quantitativas (o volume de pacientes portadoras de câncer de ovário) quanto qualitativas (ser um hospital escola ou não). Métodos: Uma coorte histórica foi estabelecida com os dados fornecidos pela Fundação Oncocentro de São Paulo (FOSP). Pacientes eram mulheres tratadas para câncer de ovário no estado de São Paulo de janeiro de 2000 a dezembro de 2018. Informação foi coletada quanto a idade, tipo histológico, estadio, cirurgia, quimioterapia e tipo do hospital. Nós classificamos os hospitais tanto quantiativamente quanto qualitativamente. Quando a mediana de número de pacientes com câncer de ovário tratados na instituição era 20 ou mais, ela era considerada um hospital de alto volume; do contrário, era considerado um hospital de baixo volume. Nós usamos a portaria interministerial do Ministério da Saúde e da Educação para determinar quais instituições eram hospitals escola; todos os outros foram classificados como hospitais regulares. Resultado: Hospitais de alto volume (HR 0.86, 95\% IC: 0.80-0.92, p < 0.001) e hospitais escola (HR 0.91, 95\% IC: 0.85$0.99, \mathrm{p}=0.019$ ) foram associados a um risco menor de morte. Probabilidade de ser submetido a cirurgia foi maior em hospitais de alto volume comparado a hospitais de baixo volume $(80.0 \%$ contra $71.1 \%, \mathrm{p}<0.001)$. Um menor número de pacientes em hospitais de alto volume foi submetido a quimioterapia comparado a hospitais de baixo volume $(68.5 \%$ contra $74.5 \%, \mathrm{p}<0.001)$. Mais de $52 \%$ dos pacientes com câncer de ovário epitelial no estado de São Paulo foram tratados em hospitais de alto volume. Conclusão: A sobrevida global foi melhor de forma independente quando o paciente foi tratado em hospitais de alto volume ou hospitais escola. A análise exploratória demonstrou uma alta porcentagem de pacientes tratados em hospitais de alto volume e um uso inesperadamente mais alto de quimioterapia em hospitais de baixo volume. Estudos adicionais são necessários para explicar esses resultados.

Palavras-chave: Câncer de ovário; Cirurgia; Epidemiologia; Sobrevida. 


\begin{abstract}
MOTERANI, V. C. Relationship between ovarian cancer survival and surgery volume in hospitals in the state of Sao Paulo. 2020. 41 f. Dissertação (Mestrado) - Faculdade de Medicina de Ribeirão Preto, Universidade de São Paulo, 2020.

Introduction: Epithelial ovarian cancer is a highly heterogenous disease. Surgery and chemotherapy both are important parts of the treatment. We assessed in this study the importance of the type of hospital in the overall survival of epithelial ovarian cancer patients. Objectives: Our goal was to identify whether hospital characteristics impacted the overall survival of the patient. We considered both quantitative characteristics (the ovarian cancer patient volume) and qualitative characteristics (being either teaching or community hospital). Methods: A retrospective cohort study was established with data recorded by the Fundação Oncocentro de São Paulo (FOSP). Patients were women treated for ovarian cancer in the state of Sao Paulo from January 2000 to December 2018. Information was gathered on age, histology, staging, surgery, chemotherapy and the type of hospital. We classified hospitals both quantitatively and qualitatively. When the median ovarian cancer number of patients treated in that institution was 20 or higher, it was considered a high-volume hospital; otherwise, it was considered a low-volume hospital. We used the interministerial ordinance by the Ministry of Health and Education to determinate which institutions were teaching hospitals; all others were classified as community hospitals. Results: High volume hospitals (HR: 0.86, 95\% CI 0.8-0.92, $\mathrm{p}<0.001$ ) and teaching hospitals (HR: 0.91, 95\% CI 0.85-0.99, $\mathrm{p}=0.019)$ were associated with low risk of death. Likelihood of undergoing surgery was higher in high-volume compared to low-volume hospitals $(80.0 \%$ versus $71.1 \%, \mathrm{p}<0.001)$. A smaller number of patients in high-volume hospitals were submitted to chemotherapy compared to low-volume hospitals $(68.5 \%$ versus $74.5 \%, \mathrm{p}<0.001)$. More than $52 \%$ of the epithelial ovarian cancer patients in the state of Sao Paulo were treated in high-volume hospitals. Conclusion: Overall survival improved independently when patients were treated in high-volume hospitals and teaching hospitals. Exploratory analysis showed a high percentage of patients treated in high-volume hospitals and an unexpected higher usage of chemotherapy in low-volume hospitals. Additional studies are required to further explain these results.
\end{abstract}

Keywords: Ovarian cancer; Surgery; Epidemiology; Survival. 


\section{LISTA DE ILUSTRAÇÕES}

Figura 1 - Identificação de coorte para câncer epitelial de ovário no estado de São Paulo

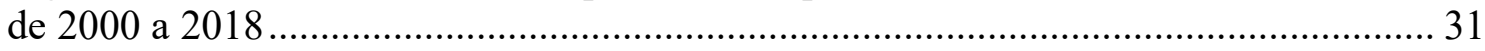

Figura 2 - Curva de Kaplan-Meyer para sobrevida em 10 anos de mulheres com câncer de ovário. 32 


\section{LISTA DE TABELAS}

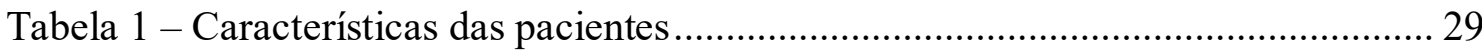

Tabela 2 - Regressão de Cox para mortalidade geral ................................................ 30 


\section{LISTA DE SIGLAS}

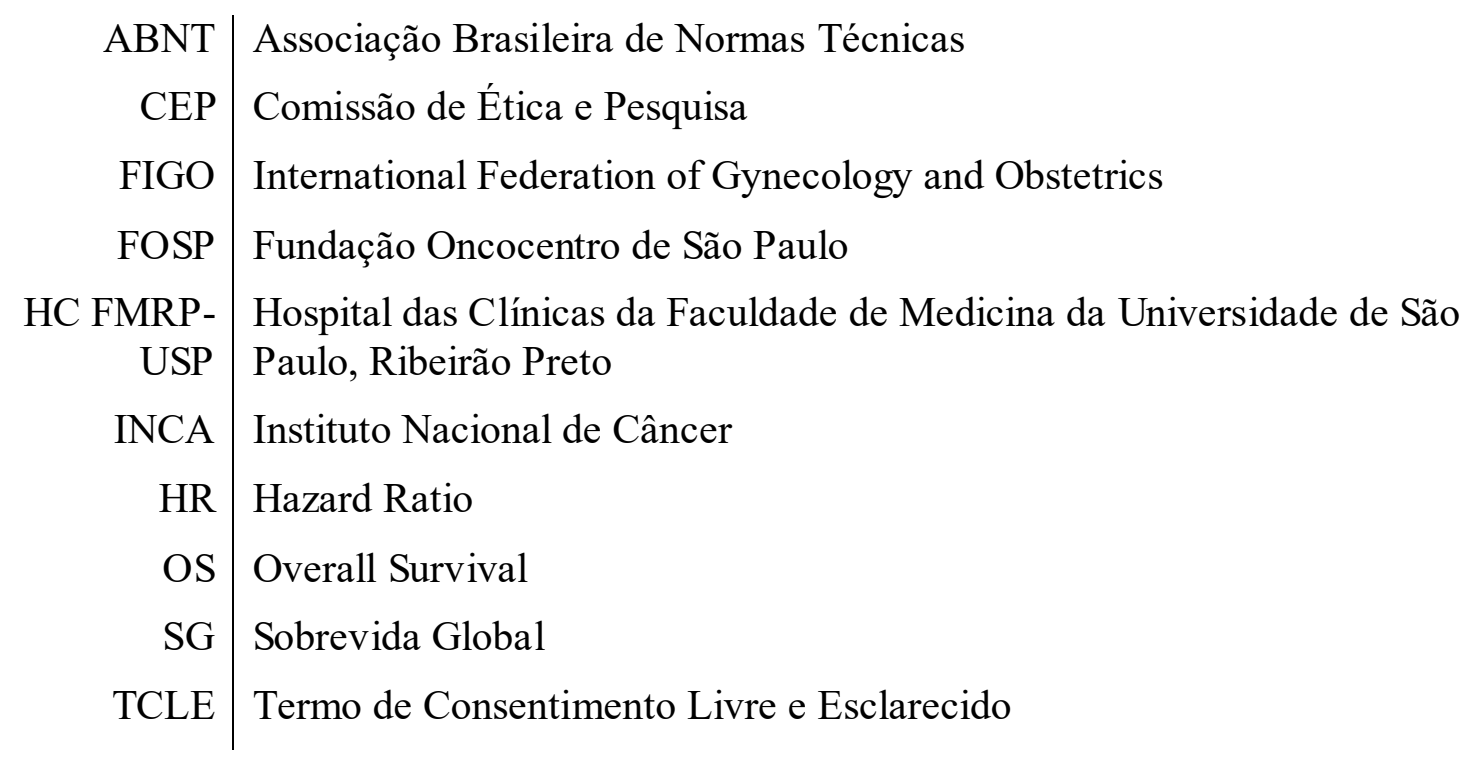




\section{SUMÁRIO}

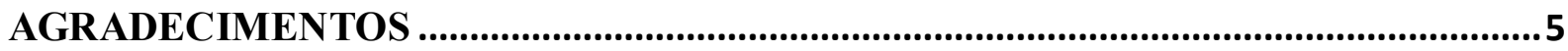

RESUMO

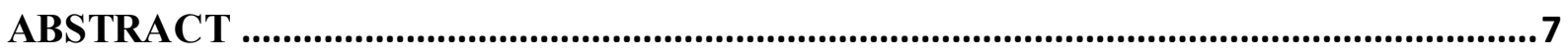

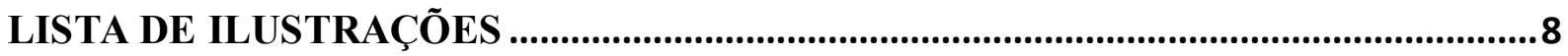

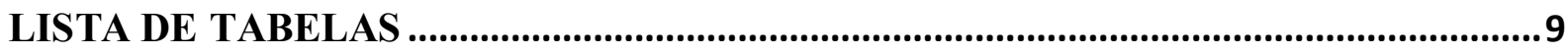

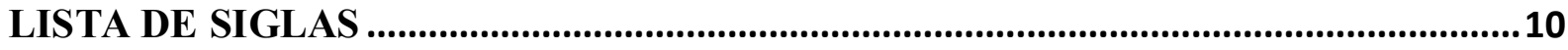

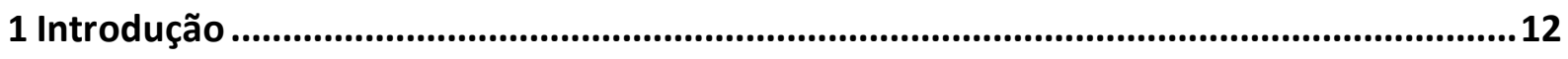

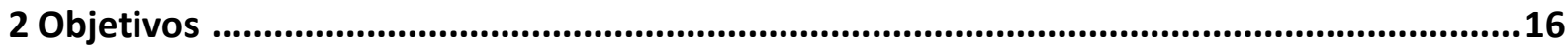

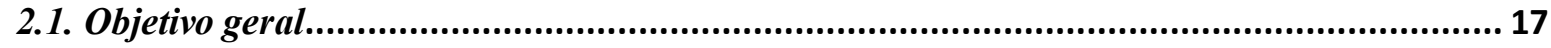

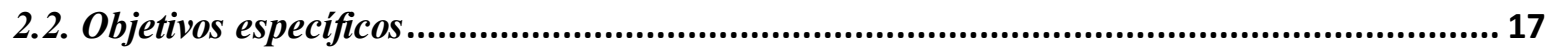

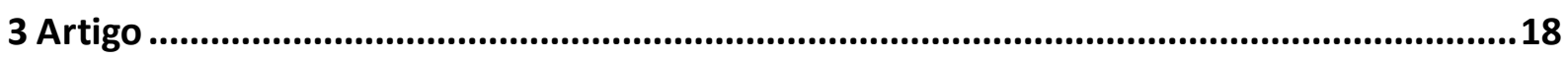

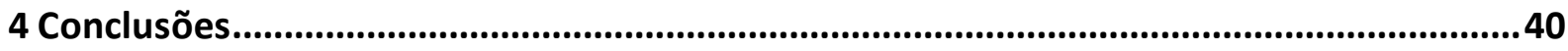

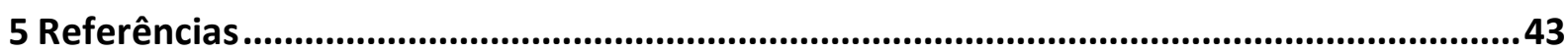

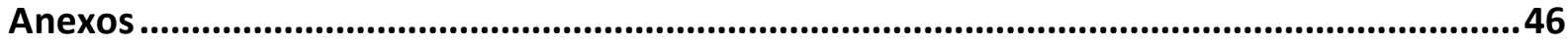

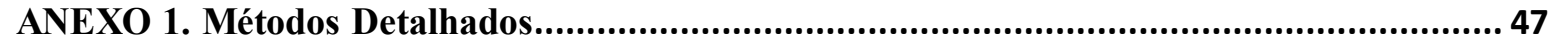

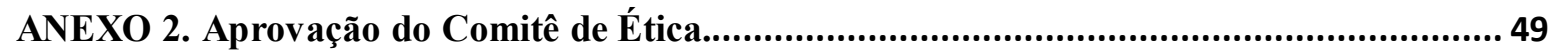


1 Introdução 
O câncer de ovário representa um desafio médico. No Brasil, trata-se da sétima neoplasia maligna mais comum, quando desconsiderados os tumores de pele não-melanoma. (INCA, 2017). Cerca de 239 mil pacientes mundialmente são diagnosticadas com câncer de ovário por ano, sendo estimados 6150 desses casos no Brasil em 2018. A magnitude do impacto na saúde pública é amplificada quando se considera a letalidade da doença associado a sua incidência: a sobrevida em 5 anos é de 30 a 40\%, e a chance de uma mulher vir a óbito por câncer de ovário ao longo de toda sua vida é de 1\%. (REID; PERMUTH; SELLERS, 2017; HOWLADER et al, 2016; MATZ et al, 2017).

Existem diferenças na distribuição, incidência e prognóstico de diferentes neoplasias malignas do ovário, a depender do tipo histológico identificado. A principal divisão se faz entre os tumors de origem epitelial e os não-epiteliais, ou seja, emergentes de células germinativas ou estroma e cordão sexual. O primeiro grupo corresponde a mais de 90\% dos casos registrados da doença, e apresentam pior prognóstico quando comparados ao segundo grupo. A análise morfológica dos tumors epiteliais permite uma categorização clinicamente relevante ainda maior, sendo agrupados como Tipo I ou Tipo II. São representantes do Tipo I as neoplasias malignas serosas de baixo grau, endometrióides, de células claras, mucinosas e de Brenner. Compõe o Tipo II as neoplasias malignas serosas de alto grau, tumores mesodermais mistos malignos e os carcinomas indiferenciados. Os pacientes acometidos pela doença do Tipo I são mais frequentes e apresentam melhor prognóstico. Tais dados sustentam a hipótese de que o cancer de ovário se trata de uma doença heterogênea, não possuindo um mecanismo fisiopatológico único. (MATZ et al, 2017).

O estadiamento do câncer de ovário é cirúrgico e patológico. Apesar da ausência de homogeneidade etiopatogênica, não se faz distinção entre os tipos de tumor no que se refere a técnica cirúrgica de estadiamento. Sustentam essa decisão a preferência por um sistema simples e reprodutível, em que se abrange os principais fatores prognóstico comuns a todos os tipos de tumores malignos ovarianos conhecidos. O estadiamento é composto por quatro categorias principais, cada uma possuindo subdivisões específicas. No primeiro estadio, a doença é confinada a ovários ou tubas uterinas. O estadio II representa a extensão pélvica da doença. No terceiro estadio, já se confirma acometimento dos linfonodos retroperitoniais ou o peritônio extra-pélvico. Por fim, o último estadio corresponde a metástases a distância, excluídas as metástases peritoneais. $\mathrm{O}$ estadiamento possui diferencia 
grupos de pacientes com diferentes prognósticos, necessitando de tratamentos específicos. (PRAT, 2014)

A cirurgia, além de definir prognóstico através do estadiamento, também tem função terapêutica. Tanto nos casos iniciais (do estadio I até IIA) quanto nos avançados (do estadio IIB até o IV), o cirurgião tem como objetivo a remoção de toda neoplasia visível, frequentemente através de histerectomia e salpingooforectomia bilateral. Os casos iniciais contam com procedimentos adicionais para definir com precisão a extensão da doença, incluindo exame e palpação de toda cavidade abdominal, omentectomia, linfadenectomia pélvica e paraaórtica, citologia peritonial e, nos casos de tumores mucinosos, apendicectomia. Em contraste, em pacientes com sinais de acometimento extra-pélvico, a prioridade passa a ser a cirurgia citorredutora: a remoção completa de todo tecido neoplásico visível. Procedimentos adicionais, como ressecção de alças intestinais, podem ser realizados. A cirurgia citorredutora será considerada ótima se não houver tumor residual com mais de 1 centímetro em seu maior diâmetro. O impacto na sobrevida será ainda maior se houver remoção completa do tumor, devendo ser esse o objetivo do cirurgião. O tratamento é complementado na maioria dos casos com quimioterapia baseada em platina. (BURGES; SCHMALFELDT, 2011)

A especialidade do médico pode modificar a qualidade do tratamento dado ao paciente. Entre pacientes candidatas a linfadenectomia pélvica e paraaórtica durante a cirurgia, esses procedimentos são realizados com maior frequência por oncologistas ginecológicos do que por ginecologistas gerais ou cirurgiões gerais. Adicionalmente, observase que que as pacientes em estadios avançados são menos frequentemente submetidas a cirurgias citorredutoras na primeira abordagem quando a cirurgia é realizada por um cirurgião geral. Quando realizada, a taxa de citorredução ótima também é maior entre os oncologistas ginecológicos quando comparados aos demais profissionais. No cenário pós-operatório, identifica-se um aumento da incidência de reabordagens cirúrgicas, com potencial atraso de tratamento adjuvante, quando o procedimento inicial não é realizado por um oncologista ginecoló gico. Um médico subespecializado aparenta fornecer cuidados mais alinhados com as melhores práticas médicas. (EARLE et al, 2006; ELIT et al, 2008; OLAITAN et al, 2001)

O impacto da intervenção médica é determinado não apenas pela formação prévia do cirurgião, mas também for fatores estruturais e dinâmicos. Essas variáveis incluem: o número de pacientes com câncer de ovário operadas em um hospital por ano; a quantidade de cirurgias para tumores ovarianos realizadas por um médico anualmente; e se a instituição 
corresponde a um hospital de ensino ou não. Melhores taxas de citorredução ótima foram obtidas em serviços com maior volume de pacientes operados por ano. (OLAITAN et al, 2001) Um número maior de pacientes operadas em hospitais universitários foram estadiadas de forma adequada, quando comparado a demais instituições. (MCGOWAN et al, 1985). Ao analisar o grupo de pacientes que simultaneamente foram operadas por cirurgiões com maiores números de cirurgias por ano e em hospitais de alto volume para esses procedimentos, identifica-se benefício na sobrevida doença-específica para câncer de ovário. (BRISTOW et al, 2013). Apesar desses benefícios, a maioria dos pacientes continua sendo tratado em serviços e equipes médicas com baixo volume anual. (BRISTOW et al, 2003; JOLLY et al, 2001; SCHRAG et al, 2006).

A análise dos desfechos de pacientes portadoras de câncer de ovário ao longo do tempo demonstra melhoria na sobrevida mediana desses pacientes. Contudo, a evolução não é homogênea quando comparados diversos subgrupos. Dentre os indivíduos mais favorecidos socioeconomicamente, a sobrevida relativa é superior aos outros grupos. Quando se considera a forma como a sobrevida evoluiu durante o tempo, nota-se que os pacientes agrupados com os melhores índices socioeconômicos obtiveram maiores incrementos de sobrevida relativa que os outros pacientes. Múltiplos fatores podem estar associados a essas diferenças, como acesso a melhores serviços de saúde ou menor taxa de realização de tratamentos não padronizados. (WU et al, 2018).

Considerando os dados expostos acima e as conclusões de estudos prévios dentro deste assunto, dividimos as características que influenciam no desfecho das pacientes em dois campos. Por um lado, consideramos o conhecimento pré-estabelecido, ou seja, aquele associado a formação e especialização da equipe, bem como a aderência a protocolos. Por outro lado, avaliamos a experiência baseada em volume, ou seja, a habilidade desenvolvida necessariamente com tratamento de um grande número de pacientes regularmente. Uma vez que não há uma qualificação oficial na especialização de oncologia ginecológica no Brasil, bem como demais limitadores para a análise do primeiro fator, alinhamos o conhecimento pré-estabelecido com o perfil dos hospitais escola, de acordo com o exposto acima sobre o perfil dessas instituições. Desta forma, estudamos o impacto da assistência prestada pelos hospitais tanto considerando o volume cirúrgico anual quanto se a instituição é um hospital de ensino ou não. Buscamos esclarecer se há um viés de confusão ou se ambas as características são independentemente relevantes na assistência prestada aos pacientes. 
2 Objetivos 


\subsection{Objetivo geral}

Comparar a sobrevida global de mulheres tratadas em diferentes hospitais uma coorte de pacientes portadoras de neoplasias malignas epiteliais de ovário.

\subsection{Objetivos especificos}

- Comparar a sobrevida global entre mulheres tratadas nos hospitais de alto volume de casos anuais de câncer de ovário e nos hospitais de baixo volume.

- Comparar a sobrevida global entre mulheres tratadas em hospitais escola e hospitais regulares.

- Avaliar o grau de centralização do tratamento de pacientes portadoras de câncer de ovário em hospitais de alto volume.

- Traçar um perfil epidemiológico das pacientes portadoras de câncer de ovário no estado de São Paulo. 
3 Artigo 


\section{1) Title}

Analysis of the relationship between hospital type and ovarian cancer survival

\section{2) Author names and affiliations.}

Vinicius C. MOTERANI, M.D. ${ }^{1}$

Daniel G. TIEZZI, M.D. ${ }^{1}$

Jurandyr M. ANDRADE, M.D ${ }^{1}$

Francisco J. CANDIDO DOS REIS, M.D. ${ }^{1}$

${ }^{1}$ Department of Gynecology and Obstetrics, Ribeirao Preto Medical School, University of Sao Paulo, Ribeirao Preto.

\section{3) Disclosure statement}

All authors report no conflicts of interest to disclose.

\section{4) Sources of financial support}

This study was financed in part by the Coordenação de Aperfeiçoamento de Pessoal de Nível Superior - Brasil (CAPES) - Finance Code 001

F. J. Candido dos Reis (grants numbers: 303210/2018-4, 427983/2016-9) was funded by the National Council for Scientific and Technological Development (CNPq).

\section{5) Study registration}

Not applicable. 
6) Paper presentation information: this was presented as a dissertation by Dr. Vinicius C. Moterani at the Post-graduation Program in Gynecology and Obstetrics of Ribeirão Preto Medical School - University of São Paulo.

\section{7) Disclaimer}

Not applicable.

\section{8) Corresponding author.}

Francisco José Candido dos Reis. Departamento de Ginecologia e Obstetrícia. Av.

Bandeirantes 3900, 8o andar, Ribeirao Preto, Brazil, 14049-900. Fax number: 5516 36021524. Telephone number: 5516 36022589. E-mail address: fjcreis@usp.br 


\section{Condensation}

Women with ovarian cancer treated in high volume and teaching hospital present better 10years survival.

\section{Short title}

Hospital type and ovarian cancer survival

\section{AJOG at a Glance}

A. Why was the study conducted?

This study was conducted to analyze whether hospital type and hospital volume affect the survival of women with epithelial ovarian cancer.

B. What are the key findings?

High volume hospitals (20 or more cases treated a year) and teaching hospitals were associated with improved ten-years survival for women with epithelial ovarian cancer.

C. What does this study add to what is already known?

This study reinforces the current understanding of the importance of the hospital surgical volume in the management of ovarian cancer and adds the description of the benefits associated with being treated in teaching hospitals.

Keywords: Hospital type; Hospital volume; Ovarian cancer; Surgery; Survival. 


\section{Structured Abstract}

1. Background: Ovarian cancer is a very lethal disease that requires complex surgical and medical interventions. Specialized care is associated with superior outcomes in early and advanced stages.

2. Objectives: We assessed in this study the association of the characteristics of the hospital (being either teaching or community hospital) and surgical volume with the overall survival of epithelial ovarian cancer patients.

3. Study Design: A retrospective cohort study was established with data recorded by the Fundação Oncocentro de São Paulo cancer registry. We included 8,069 women treated for ovarian cancer in the state of Sao Paulo from January 2000 to December 2018. From 76 hospitals, seven were high volume (20 or more cases a year) and 69 low volume. Twenty-nine were teaching and 47 community hospitals. Ten years' survival was analyzed using the Kaplan-Meyer estimator and Cox model.

4. Results: High volume hospitals (HR: 0.86, 95\% CI 0.8-0.92, p < 0.001) and teaching hospitals (HR: $0.91,95 \%$ CI $0.85-0.99, \mathrm{p}=0.019$ ) were associated with low risk of death. The likelihood of undergoing surgery was higher in high-volume compared to low-volume hospitals $(80.0 \%$ versus $71.1 \%, \mathrm{p}<0.001)$. A smaller number of patients in high-volume hospitals were submitted to chemotherapy compared to low-volume hospitals $(68.5 \%$ versus $74.5 \%, \mathrm{p}<0.001)$. More than $52 \%$ of the epithelial ovarian cancer patients in the state of Sao Paulo were treated in high-volume hospitals.

5. Conclusion: High volume and teaching hospitals are associated with better overall survival in ovarian cancer. The results are important both for individual care of patients and for design models of care in ovarian cancer. 


\section{Introduction}

Ovarian cancer is a health care challenge. About 239.000 patients each year are diagnosed with ovarian cancer around the world. The disease is highly heterogeneous, with different types and morphological subtypes favoring different outcomes. The most common type of these tumors is the epithelial malignant neoplasm of the ovary, accounting for over $90 \%$ of all cases $[1,2]$.

The optimum management of epithelial ovarian cancer (EOC) is dependent on expertise in surgery, chemotherapy, imaging, histopathology, and palliation [3]. Surgery plays a major role both in the staging and treatment of the disease. Correct staging is paramount to determinate the best adjuvant treatment. Previous studies have identified the specialization of the surgeon as a vital factor regarding more accurate staging, as gynecologic oncologists performed higher rates of lymphadenectomy in early-stage ovarian cancer than general gynecologists or general surgeons. In the advanced setting, better rates of optima cytoreductive surgery were obtained by gynecologic oncologists than their counterparts [4-6]. Attention has also been given to the hospital themselves. It has been shown that patients treated in teaching hospitals were better staged than those in community hospitals. Hospitals caring for larger volumes of ovarian cancer patients yearly also exhibited better results, with patients having better odds of achieving optimal cytoreduction in these institutions [7-9]. These findings highlight the importance of abiding by standard techniques and treatment, the specialized training of the surgeon and the experience obtained by managing a higher number of patients every year.

Since 2000, the Sao Paulo state (Brazil) maintains a hospital-based cancer registry. Currently, the registry collects data from 77 hospitals [10]. This study aimed to determine the effect of being treated in high volume hospitals and teaching hospitals (as a surrogate of physician specialization and adherence to protocols), on long-term survival in women with EOC. 


\section{Materials and Methods}

\subsection{Study design}

This study was designed as a retrospective cohort study. The participants are women treated for epithelial ovarian cancer in the state of Sao Paulo from January 2000 to December 2018. We used overall survival as the primary endpoint.

The study was approved, and the requirement of written informed consent was waived by the institutional review board of the Hospital das Clinicas da Faculdade de Medicina de Ribeirão Preto da Universidade de São Paulo (CAAE: 66233317.5.0000.5440). The study was performed in accordance with the Declaration of Helsinki.

\subsection{Population and exclusion criteria}

The Fundação Oncocentro de São Paulo (FOSP) provided a file containing the data from 10,311 patients with ovarian tumors from Sao Paulo state. The patients were included in the registry from January 2000 to December 2018. We followed by excluding nine duplicated cases, 372 patients under 18 years old and a total of 1,861 women with non-epithelial or borderline tumors. From survival analysis, we excluded 118 additional women without follow up and 1,840 women not undergone surgery.

\subsection{Variables}

Terms, definitions, and staging systems for cases recorded in the RHC/FOSP varied throughout the years. Therefore, we harmonized the variables. The variables selected from the database were: date of birth, stage, histology, date of diagnosis, surgery, chemotherapy, date of last follow up, and status at the last follow up. Age was calculated in years at the date of patient diagnosis. The stage was provided according to FIGO Nomenclature and, to maintain the uniformity, harmonized according to SEER summary stage in three groups: localized 
(stages: I, IA, IB, IC), regional (stages: II, IIA, IIB, IIC, IIIA), and distant (stages: III, IIIB, IIIC, IV). Patients were also grouped according to histology: serous, mucinous, endometrioid, clear cell, epithelial without histotype specification, and undifferentiated carcinoma. Because there was no detail available about the type of surgery and chemotherapy, these variables were dichotomized in yes/no. Survival time was calculated in years by subtracting the date of diagnosis from the date of the last follow up. The patient statuses at the last follow up were: alive, died of ovarian cancer or died of other causes. Hospital level was classified as high volume if the median of the number of cases operated a year was 20 or more. Otherwise, the hospital was classified as low volume. Hospitals were also classified as teaching hospitals or community hospitals. We considered teaching hospitals those listed in the official interministerial ordinance issued by the Ministry of Health and the Ministry of Education [11], all other hospitals were considered community hospitals.

\subsection{Statistical Analysis}

Data manipulation and statistical analysis were carried out using RStudio (Rstudio: Integrated Development for R. RStudnio, Inc., Boston, MA. http:/www.rstudio.com/). Summary statistics were used to compare the variables from women treated in high volume and low volume hospitals. For survival analysis, cases were right censored at ten years of follow up. Kaplan-Meyer estimator was used to estimate overall survival. To evaluate the adjusted impact of high volume and teaching hospital on all-cause mortality, we used the Cox proportional hazard model. 


\section{Results}

We identified patients treated in 76 hospitals. Seven hospitals were high volume and 69 low volume. Among high volume hospitals five (71\%) were teaching hospitals and two (29\%) community hospitals. Among the low volume hospitals $24(35 \%)$ were teaching hospitals and $45(65 \%)$ community hospitals.

A total of 8,069 cases were suitable for analysis after all exclusion criteria were applied. Of these, $52.1 \%(4,211)$ were treated in high volume hospitals, and $47.9 \%(3,858)$ were treated in low volume hospitals; $61.5 \%(4,959)$ were treated in teaching hospitals and $38.5 \%(3,110)$ in community hospitals.

Characteristics of patients treated in high and low volume hospitals are presented in Table $\mathbf{1 .}$ The proportion of localized tumors were similar in both types of hospitals. We identified differences in the reported histological subtype of epithelial ovarian cancer among high and low volume hospitals. There was a higher rate of "not otherwise specified" subtype among the low-volume hospital patients.

A higher percentage of patients underwent surgery in high-volume hospitals than their lowervolume counterparts. Conversely, low-volume hospitals had a higher rate of patients submitted to chemotherapy than high-volume institutions.

In Figure 2 is shown the survival curves for patients treated in high and low volume hospitals. The median survival time was 3.83 years $(95 \% \mathrm{CI}, 3.52-4.15)$ for patients from low volume hospitals and 5.03 years $(95 \%$ CI, 4.73 - 5.58) for patients from high volume hospitals (logrank test, $\mathrm{p}<0.0001$ ).

Multivariate Cox regression for all-cause mortality is shown in Table 2. High volume hospitals (HR: 0.86, 95\% CI 0.8-0.92, $\mathrm{p}<0.001)$ and teaching hospitals (HR: $0.91,95 \% \mathrm{CI}$ $0.85-0.99, \mathrm{p}=0.019)$ were associated with lower risk of death. 


\section{Structured Discussion}

\subsection{Principal Findings}

We found a significantly better overall survival for ovarian cancer patients treated in both high-volume hospitals and teaching hospitals. These results confirm the hypothesis of both quantitative and qualitative hospital characteristics as being relevant for the treatment outcome.

\subsection{Results}

To our knowledge, there is no other available data considering together the impact of teaching hospitals and high-volume hospitals in the overall survival of ovarian cancer patients. There are, however, previous studies showing favorable outcomes for patients treated in highvolume settings, such as improved disease-specific survival [12] and improved cytoreductive rates [9]. Our results contrast with those published by Schrag [13], in which there was no overall survival benefit. It must be considered several differences between these two studies which might explain the different results. First, our definition of low and high-volume hospitals is not the same. Schrag included institutions caring for at least 29 patients over an 8year period. We based our analysis on the definitions used by Bristow [12] in his study, requiring a median of at least 20 operated ovarian cancer patients per year. Additionally, Schrag's population were Medicare beneficiaries. Our study includes information from both private-funded and public hospitals. In our cohort, over $52 \%$ of patients were operated in high-volume scenarios. This data differs from all published proportion [9, 13, 14]. Even when comparing with Bristow $[8,12]$, which used the same criteria as we used to define low and high-volume hospitals, our population shows higher access to these specific institutions.

We identified differences in the reported histological subtype of epithelial ovarian cancer among high and low volume hospitals. There was a higher rate of "not otherwise specified" subtype among the low-volume hospital patients. Additionally, all other subtypes show very 
similar rates between both groups. We suspect this difference arises not from a real epidemiological difference among types of patients, but rather due to lower experience in dealing with ovarian cancer among members of the pathology service in low-volume hospitals.

Patients treated in high-volume hospitals were more likely to be submitted to surgery $(80.0 \%$ versus $71.1 \%, p<0.001)$. This result is coherent with data previously reported by Long et al., in a population of stage IIIC and IV ovarian cancer patients, in which high-volume hospital patients were more likely to be operated [15].

On the other hand, we found higher rates of chemotherapy in low-volume hospitals patients than their high-volume counterparts, even considering there is no significant difference in staging among the two groups $(74.5 \%$ versus $68.5 \%, \mathrm{p}<0.001)$. Our finding seems to conflict with published data on this aspect, which could arise from possible differences in the profile of physicians in high-volume hospitals in our country. For instance, previous studies reported a higher rate of chemotherapy among patients treated by specialized physicians, which are also usually high-volume physicians themselves $[13,15,16]$. Our data showed a higher concentration of patients in high-volume institutions than seem in previous studies. It is possible that patients treated in high-volume hospitals had to travel long distances to receive treatment, and a higher number of patients might have chosen to decline chemotherapy due to this factor. While previous studies have considered the impact of geographical location on ovarian cancer outcomes [17], this specific question still cannot be answered by available data. Another possibility would be the occurrence of overtreatment among patients treated in low volume hospitals. If there was indeed overtreatment, it might also help explain why overall survival was inferior in low-volume hospitals, as unnecessary toxicity might contribute to the inferior results. The reported adherence to standard chemotherapy protocols is higher among high-volume hospitals [8]. The surprising chemotherapy data could also be 
associated with the number of patients not submitted to surgery. It is possible a higher number of patients in low-volume hospitals were offered neoadjuvant chemotherapy and subsequently were not operated for several reasons, such as toxicity or inadequate response [15]. As a final consideration, we do not have data available on patient morbidity. However, since highvolume hospitals had higher surgery rates, we cannot find evidence to consider these institutions had patients with higher morbidity rates, unfit for chemotherapy.

\subsection{Clinical Implications}

The results highlight the importance of both quantitative and qualitative characteristics of hospitals treating ovarian cancer patients. The identification of both variables as independent and relevant might help the development of public health policies. As cancer treatment evolves, fostering teaching hospitals, and concentrating ovarian cancer surgery in regional reference centers can be an essential strategy to achieve better survival, in concordance with published results [18]. Our country lacks an official certification for gynecologic oncologists, and surgical gynecologic oncology is currently part of two specialties: surgical oncology and obstetrics and gynecology [19]. We expect this data to help determine the criteria for future residency programs in the field. The results suggest the best results arise from both highvolume and teaching hospitals. Compliance with both requirements could be considered necessary for a future residency program in the field.

\subsection{Research Implications}

One important question is whether these results are specific for ovarian cancer or a general concept for the management of all gynecological malignancies. Correlation with other studies about the most common gynecologic cancers, such as cervical cancer, is necessary for further conclusions.

\subsection{Strengths and Limitations}


This study presents as strengths the large cohort size and the simultaneous analysis of hospital volume and hospital characteristics (teaching versus community hospital). The considerable number of patients treated in high-volume hospitals in our study is both a strength and an interesting epidemiological finding. The limitations are inherent to the retrospective nature of our analysis. Additionally, we could not account for the physician's yearly patient volume, as done in previous studies. Furthermore, we used teaching hospitals as a surrogate for adherence to standardized treatments and surgeon specialization. It must be considered that our country does not have official qualifications for gynecologic oncologists, thus requiring the use of other variables to assess these criteria. Finally, the unexpectedly high usage of chemotherapy in low-volume hospitals might limit future data comparison.

\subsection{Conclusions}

In conclusion, our study demonstrates an improvement in the overall survival of epithelial ovarian cancer patients operated both in high-volume hospitals and teaching hospitals. The improvement in overall survival was clinically significant in this large cohort. Patients with suspected or confirmed epithelial ovarian cancers should be treated in high-volume teaching hospitals, when available. Furthermore, the epidemiological data identified on an exploratory analysis highlights differences between the healthcare structure available in the state of Sao Paulo and those reported mainly in the United States and the United Kingdom. Additional studies are warranted in order to better comprehend these findings.

\section{Authorship}

Conceived and designed the study: V. C.M., and F.J.C.R.

Analyzed data: F.J.C.R.

Helped with writing the first draft of the manuscript: All authors.

Provided critical insight and revision to manuscript: All authors. 


\section{References}

1. Reid BM, Permuth JB, Sellers TA (2017) Epidemiology of ovarian cancer: a review. Cancer Biol Med 14:9-32. https://doi.org/10.20892/j.issn.2095-3941.2016.0084

2. Matz M, Coleman MP, Sant M, et al (2017) The Histology of Ovarian Cancer: Worldwide Distribution and Implications for International Survival Comparisons (CONCORD-2). Gynecol Oncol 144:405-413. https://doi.org/10.1016/j.ygyno.2016.10.019 3. Jayson GC, Kohn EC, Kitchener HC, Ledermann JA (2014) Ovarian cancer. The Lancet 384:1376-1388. https://doi.org/10.1016/S0140-6736(13)62146-7

4. Prat J (2014) Staging classification for cancer of the ovary, fallopian tube, and peritoneum. International Journal of Gynecology \& Obstetrics 124:1-5. https://doi.org/10.1016/j.ijgo.2013.10.001

5. Burges A, Schmalfeldt B (2011) Ovarian cancer: diagnosis and treatment. Dtsch Arztebl Int 108:635-641. https://doi.org/10.3238/arztebl.2011.0635

6. Elit LM, Bondy SJ, Paszat LP, et al (2008) Surgical outcomes in women with ovarian cancer. Can J Surg 51:346-354

7. McGowan L, Lesher LP, Norris HJ, Barnett M (1985) Misstaging of Ovarian Cancer. Obstetrics \& Gynecology 65:568-572

8. Bristow R, Chang J, Ziogas A, Anton-Culver H (2013) NCCN treatment guidelines for ovarian cancer: A population-based vali- dation study of structural and process quality measures. Gynecologic Oncology 130:e18. https://doi.org/10.1016/j.ygyno.2013.04.104 9. Olaitan A, Weeks J, Mocroft A, et al (2001) The surgical management of women with ovarian cancer in the south west of England. Br J Cancer 85:1824-1830.

https://doi.org/10.1054/bjoc.2001.2196

10. FOSP - Fundação Oncocentro de São Paulo. http://fosp.saude.sp.gov.br/publicacoes/registrohospitalardecancer. Accessed 16 Feb 2020 
11. PORTARIA INTERMINISTERIAL Nº 2.302, DE 30 DE JULHO DE 2018 Imprensa Nacional. http://www.in.gov.br/materia. Accessed 15 Feb 2020

12. Bristow RE, Chang J, Ziogas A, et al (2014) High-volume ovarian cancer care: survival impact and disparities in access for advanced-stage disease. Gynecol Oncol 132:403410. https://doi.org/10.1016/j.ygyno.2013.12.017

13. Schrag D, Earle C, Xu F, et al (2006) Associations between hospital and surgeon procedure volumes and patient outcomes after ovarian cancer resection. J Natl Cancer Inst 98:163-171. https://doi.org/10.1093/jnci/djj018

14. Jolly K, Parry J, Rouse A, Stevens A (2001) Volumes of cancer surgery for breast, colorectal and ovarian cancer 1992-97: is there evidence of increasing sub-specialization by surgeons? Br J Cancer 84:1308-1313. https://doi.org/10.1054/bjoc.2001.1794

15. Long B, Chang J, Ziogas A, et al (2015) Impact of race, socioeconomic status, and the health care system on the treatment of advanced-stage ovarian cancer in California. American Journal of Obstetrics and Gynecology 212:468.e1-468.e9.

https://doi.org/10.1016/j.ajog.2014.10.1104

16. Earle CC, Schrag D, Neville BA, et al (2006) Effect of Surgeon Specialty on Processes of Care and Outcomes for Ovarian Cancer Patients. J Natl Cancer Inst 98:172-180. https://doi.org/10.1093/jnci/djj019

17. Bristow RE, Chang J, Ziogas A, et al (2015) Spatial analysis of advanced-stage ovarian cancer mortality in California. Am J Obstet Gynecol 213:43.e1-43.e8. https://doi.org/10.1016/j.ajog.2015.01.045

18. Dahm-Kähler P, Palmqvist C, Staf C, et al (2016) Centralized primary care of advanced ovarian cancer improves complete cytoreduction and survival - A population-based cohort study. Gynecol Oncol 142:211-216. https://doi.org/10.1016/j.ygyno.2016.05.025 
19. Johnston C, $\mathrm{Ng} \mathrm{JS}$, Manchanda R, et al (2017) Variations in gynecologic oncology training in low (LIC) and middle income (MIC) countries (LMICs): Common efforts and challenges. Gynecol Oncol Rep 20:9-14. https://doi.org/10.1016/j.gore.2017.01.003 
Table 1. Characteristics of patients according to the volume of hospital.

\begin{tabular}{|c|c|c|c|}
\hline Variable & Low Volume & High Volume & $\mathrm{p}$ \\
\hline $\mathrm{n}$ & 3858 & 4211 & \\
\hline Age (mean (SD)) & $57.70(13.08)$ & $57.27(13.11)$ & 0.145 \\
\hline Histology (\%) & & & $<0.001$ \\
\hline Brenner & $18(0.5)$ & $8(0.2)$ & \\
\hline Clear cell & $93(2.4)$ & $158(3.8)$ & \\
\hline Endometrioid & $175(4.5)$ & $253(6.0)$ & \\
\hline Epithelial (NOS) & $1641(42.5)$ & $968(23.0)$ & \\
\hline Mucinous & $490(12.7)$ & $598(14.2)$ & \\
\hline Serous & $1363(35.3)$ & $2201(52.3)$ & \\
\hline Undifferentiated & $78(2.0)$ & $25(0.6)$ & \\
\hline Stage $(\%)$ & & & $<0.001$ \\
\hline Localized & $897(23.3)$ & $1000(23.7)$ & \\
\hline Regional & $543(14.1)$ & $382(9.1)$ & \\
\hline Distant & $2242(58.1)$ & $2508(59.6)$ & \\
\hline Missing & $176(4.6)$ & $321(7.6)$ & \\
\hline Surgical treatment $(\%)$ & $2742(71.1)$ & $3369(80.0)$ & $<0.001$ \\
\hline Chemotherapy (\%) & $2873(74.5)$ & $2886(68.5)$ & $<0.001$ \\
\hline Teaching hospital (\%) & $1906(49.4)$ & $3053(72.5)$ & $<0.001$ \\
\hline
\end{tabular}


Table 2. Cox regression for all-cause mortality.

\begin{tabular}{|c|c|c|c|}
\hline Variable & HR & $95 \% \mathrm{CI}$ & $\mathrm{p}$ \\
\hline \multicolumn{4}{|l|}{ Hospital volume } \\
\hline Low Volume & Ref & & \\
\hline High Volume & 0.86 & $(0.8-0.92)$ & $<0.001$ \\
\hline Age & 1.02 & $(1.01-1.02)$ & $<0.001$ \\
\hline \multicolumn{4}{|l|}{ SEER stage } \\
\hline Localized & Ref & & \\
\hline Regional & 3.2 & $(2.74-3.75)$ & $<0.001$ \\
\hline Distant & 6.89 & $(6.07-7.83)$ & $<0.001$ \\
\hline Missing & 4.13 & $(3.46-4.93)$ & $<0.001$ \\
\hline \multicolumn{4}{|l|}{ Histology } \\
\hline Serous & Ref & & \\
\hline Brenner & 0.67 & $(0.37-1.21)$ & 0.186 \\
\hline Clear cell & 1.24 & $(0.99-1.56)$ & 0.060 \\
\hline Endometrioid & 0.73 & $(0.61-0.88)$ & 0.001 \\
\hline Epithelial, NOS & 1.26 & $(1.16-1.37)$ & $<0.001$ \\
\hline Mucinous & 1.11 & $(0.99-1.25)$ & 0.083 \\
\hline Undifferentiated & 1.31 & $(0.94-1.83)$ & 0.108 \\
\hline \multicolumn{4}{|l|}{ Chemotherapy } \\
\hline No & Ref & & \\
\hline Yes & 0.49 & $(0.45-0.54)$ & $<0.001$ \\
\hline \multicolumn{4}{|l|}{ Hospital type } \\
\hline Community & Ref & & \\
\hline Teaching & 0.91 & $(0.85-0.99)$ & 0.019 \\
\hline
\end{tabular}




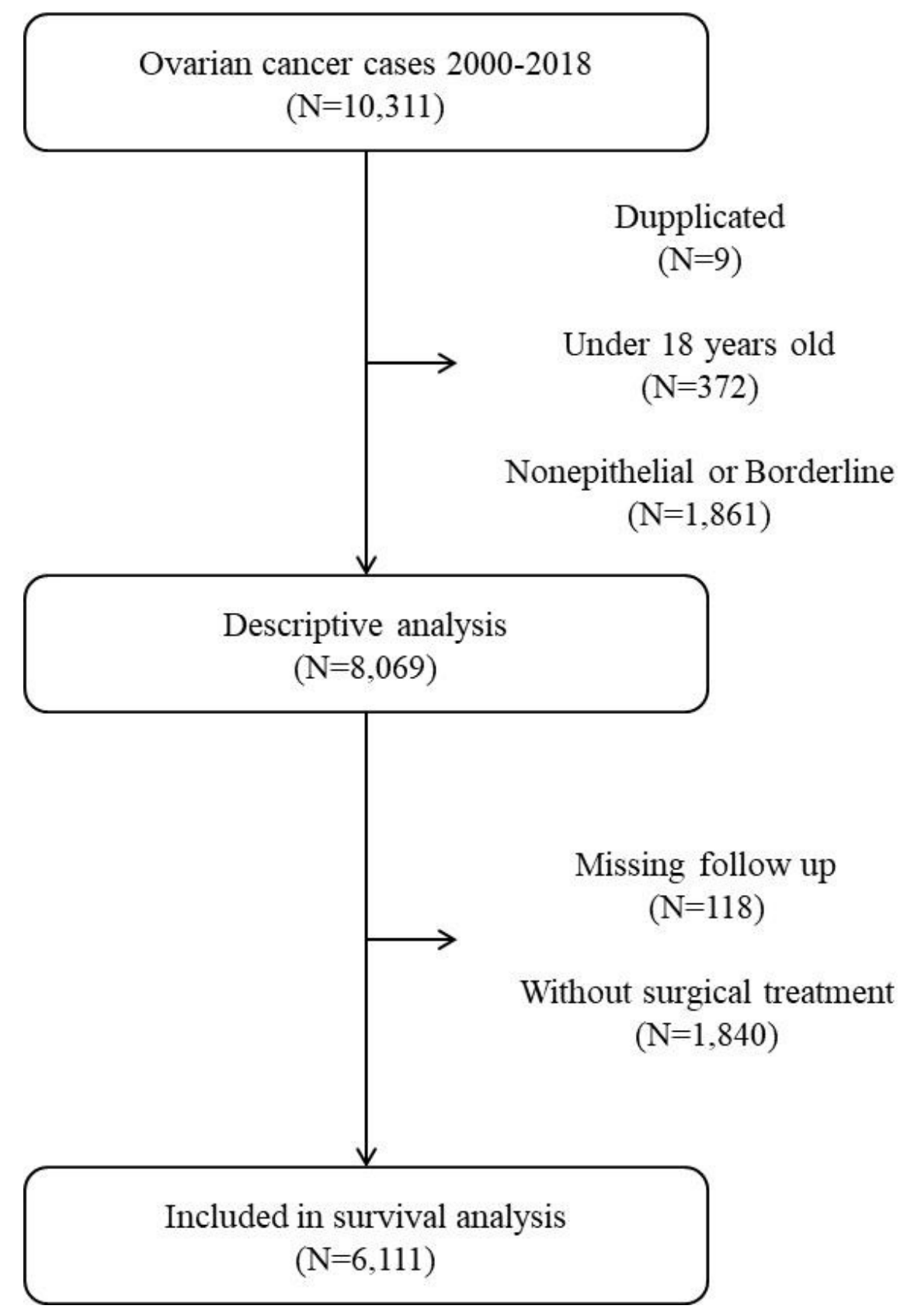

Figure 1. Cohort identification for epitelial ovarian câncer in São Paulo state from 2000 to 2018. 


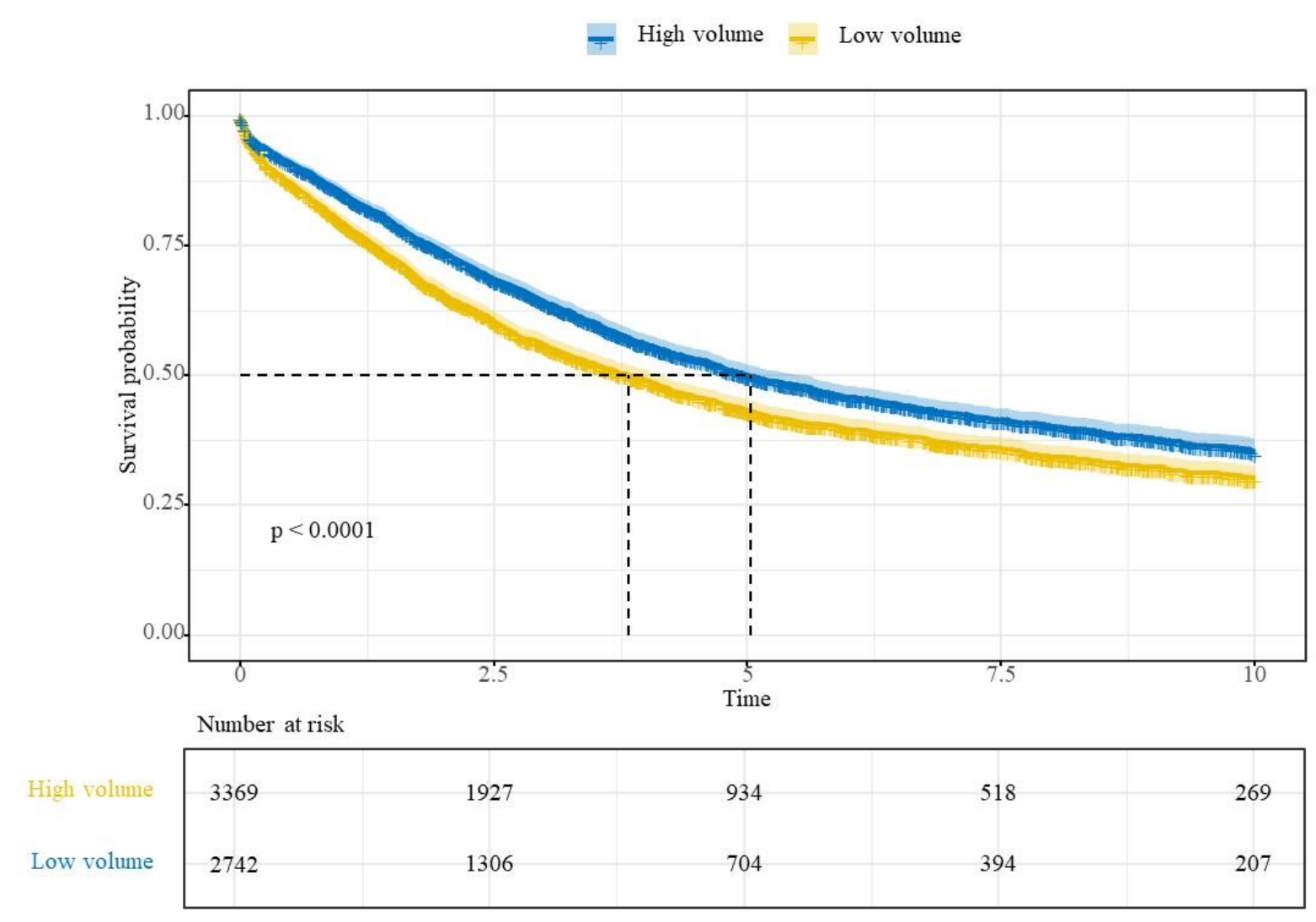

Figure 2. Kaplan Meyer survival curves, according to the hospital volume. 
4 Conclusões 
A análise dos dados demonstra uma sobrevida global superior entre pacientes portadoras de câncer epitelial de ovário tratadas em hospitais de alto volume de casos anuais. Adicionalmente, também identifica-se um incremento na sobrevida global dentre as pacientes tratadas em hospitais escola.

A maioria dos pacientes recebeu tratamento em instituições de alto volume de casos anuais. Este dado contrasta com os demonstrados em estudos americanos e ingleses, sugerindo que a estrutura paulista de serviços de saúde para este tratamento é mais centralizada.

A análise exploratória dos dados nos permitiu identificar uma taxa superior de realização de cirurgia nas pacientes portadoras de neoplasia maligna epitelial de ovário tratadas em hospitais de alto volume. Quanto a taxa de realização de quimioterapia, ocorre o inverso: realiza-se mais em hospitais de baixo volume. Esta informação se torna ainda mais relevante quando considerado que o estadiamento dentre os dois grupos é muito semelhante. A natureza do estudo e a disposição dos dados não permitem uma conclusão definitiva sobre a razão desta diferença. Em função do maior número de pacientes operados no primeiro grupo, consideramos improvável a hipótese que este concentre uma maior quantidade de pacientes de alta morbidade, inadequados para realização de quimioterapia. É possível que pacientes tratados em hospitais de alto volume necessitem de longas viagens para comparecer ao atendimento médico e tenham recusado a realização de quimioterapia. Consideramos ainda a possibilidade de indicação excessiva de quimioterapia em hospitais de baixo volume. Adicionalmente, uma possibilidade é uma maior frequência de tratamentos neoadjuvantes dentre as pacientes em hospitais de baixo volume, sendo que algumas dessas pacientes seriam inelegíveis para cirurgia após iniciado tratamento clínico. Maiores estudos são necessários para melhor compreender tal fenômeno e confirmar ou afastar as hipóteses acima.

Os resultados apontados no presente estudo demonstram o benefício para este grupo de pacientes em serem tratados em hospitais de ensino e de alto volume cirúrgico. Tais dados podem guiar políticas de saúde pública futuras. $\mathrm{O}$ incentivo ao desenvolvimento de hospitais de ensino, bem como a centralização do tratamento em instituições de concentrem os pacientes a serem operados, podem ser mecanismos para aprimorar os desfechos dessa população.

Ainda deve se considerar que não há uma certificação oficial em nosso país para os especialistas em oncologia ginecológica. Os resultados deste estudo podem ajudar a 
estabelecer critérios para futuros programas de residência médica nesta área. Correlação com outros estudos a respeito das neoplasias ginecológicas mais comuns é necessária para maiores conclusões sobre uma hipotética residência nesta subespecialidade.

Por fim, concluímos que a característica de ensino de um hospital, bem como o fator de alto volume cirúrgico anual, são ambos fatores significativos de forma independente para a sobrevida global de pacientes tratados cirurgicamente para câncer epitelial de ovário. Pacientes com casos suspeitos ou confirmados da doença devem ser referenciados para tratamento em instituições com este perfil, quando disponíveis. A análise exploratória dos dados torna evidente as diferenças na estrutura do sistema de saúde paulista quando comparados ao americano ou ao inglês. Estudos adicionais são necessários para melhor compreender tais fenômenos. 
5 Referências 
BRISTOW, R. et al. NCCN treatment guidelines for ovarian cancer: A population-based validation study of structural and process quality measures. Gynecologic Oncology, v. 130, n. 1, p. e18, 1 jul. 2013.

BRISTOW, R. et al. Ovarian Cancer Surgery in Maryland: Volume-Based Access to Care. Gynecologic Oncology 93, n. 2, p. 353-60, maio, 2004.

BRISTOW, R. E. et al. High-volume ovarian cancer care: survival impact and disparities in access for advanced-stage disease. Gynecologic Oncology, v. 132, n. 2, p. 403-410, fev. 2014.

BRISTOW, R. E. et al. Spatial analysis of advanced-stage ovarian cancer mortality in California. American Journal of Obstetrics and Gynecology, v. 213, n. 1, p. 43.e1-43.e8, jul. 2015.

BURGES, A.; SCHMALFELDT, B. Ovarian cancer: diagnosis and treatment. Deutsches Arzteblatt International, v. 108, n. 38, p. 635-641, set. 2011.

DAHM-KÄHLER, P. et al. Centralized primary care of advanced ovarian cancer improves complete cytoreduction and survival - A population-based cohort study. Gynecologic Oncology, v. 142, n. 2, p. 211-216, 2016.

EARLE, C. C. et al. Effect of Surgeon Specialty on Processes of Care and Outcomes for Ovarian Cancer Patients. JNCI: Journal of the National Cancer Institute, v. 98, n. 3, p. 172 180, 1 fev. 2006.

ELIT, L. M. et al. Surgical outcomes in women with ovarian cancer. Canadian Journal of Surgery, v. 51, n. 5, p. 346-354, out. 2008.

FOSP - Fundação Oncocentro de São Paulo. Disponível em:

$<$ http://fosp.saude.sp.gov.br/publicacoes/registrohospitalardecancer $>$. Acesso em: 16 fev. 2020.

JAYSON, G. C. et al. Ovarian cancer. The Lancet, v. 384, n. 9951, p. 1376-1388, 11 out. 2014. 
JOHNSTON, C. et al. Variations in gynecologic oncology training in low (LIC) and middle income (MIC) countries (LMICs): Common efforts and challenges. Gynecologic Oncology Reports, v. 20, p. 9-14, 9 jan. 2017.

JOLLY, K. et al. Volumes of cancer surgery for breast, colorectal and ovarian cancer 199297: is there evidence of increasing sub-specialization by surgeons? British Journal of Cancer, v. 84 , n. 10 , p. 1308-1313, maio 2001.

LONG, B. et al. Impact of race, socioeconomic status, and the health care system on the treatment of advanced-stage ovarian cancer in California. American Journal of Obstetrics and Gynecology, v. 212, n. 4, p. 468.e1-468.e9, 1 abr. 2015.

MATZ, M. et al. The Histology of Ovarian Cancer: Worldwide Distribution and Implications for International Survival Comparisons (CONCORD-2). Gynecologic oncology, v. 144, n. 2, p. 405-413, fev. 2017.

MCGOWAN, L. et al. Misstaging of Ovarian Cancer. Obstetrics \& Gynecology, v. 65, n. 4, p. 568-572, abr. 1985.

OLAITAN, A. et al. The surgical management of women with ovarian cancer in the south west of England. British Journal of Cancer, v. 85, n. 12, p. 1824-1830, dez. 2001.

PORTARIA INTERMINISTERIAL No 2.302, DE 30 DE JULHO DE 2018 - Imprensa Nacional. Disponível em: <http://www.in.gov.br/materia>. Acesso em: 15 fev. 2020.

PRAT, J. Staging classification for cancer of the ovary, fallopian tube, and peritoneum. International Journal of Gynecology \& Obstetrics, v. 124, n. 1, p. 1-5, 2014.

REID, B. M.; PERMUTH, J. B.; SELLERS, T. A. Epidemiology of ovarian cancer: a review. Cancer Biology \& Medicine, v. 14, n. 1, p. 9-32, fev. 2017.

SCHRAG, D. et al. Associations between hospital and surgeon procedure volumes and patient outcomes after ovarian cancer resection. Journal of the National Cancer Institute, v. 98, n. 3, p. 163-171, 1 fev. 2006. 
Anexos 


\section{ANEXO 1. Métodos Detalhados}

Desenho do Estudo

Trata-se de um estudo observacional populacional tipo coorte histórica. Os sujeitos do estudo foram mulheres com diagnóstico de neoplasia epitelial maligna do ovário. As participantes foram tratadas no Estado de São Paulo, em instituições públicas e particulares, de janeiro de 2000 a julho de 2019. Os dados foram obtidos pela Fundação Oncocentro de São Paulo (FOSP) e compartilhados para realização desta pesquisa. O estudo foi aprovado pela Comissão de Ética e Pesquisa (CEP) do Hospital das Clínicas da Faculdade de Medicina de Ribeirão Preto da Universidade de São Paulo (CAAE: 66233317.5.0000.5440), com concessão de Isenção do Termo de Consentimento Livre e Esclarecido (TCLE).

\section{Casuística}

Foram identificados 10311 casos no banco de dados trabalhado. Do total inicial, foram excluídos 9 casos duplicados, 372 casos de pacientes abaixo de 18 anos e 1861 casos de tumores não ovarianos, não epiteliais ou tipo borderline. Desta forma, permaneceram 8069 casos compondo a amostra para análise descritiva. Destes, foram excluídos 1840 pacientes sem tratamento cirúrgico e 118 pacientes sem follow up, permitindo uma análise de sobrevida sobre um total de 6111 pacientes operadas.

\section{Variáveis}

As variáveis coletadas foram: data de nascimento, estadio, tipo histológico, data do diagnóstico, cirurgia, quimioterapia, data da última avaliação de acompanhamento e estado na última avaliação de acompanhamento. Idade foi calculada em anos na data do diagnóstico. Estadio foi fornecido de acordo com a padronização da FIGO. Considerando a mudança de estadiamento para câncer de ovário pela FIGO em 2014, e buscando melhor harmonização dos dados, tornou-se necessária a uniformização dos grupos. Em função do estadio, foram uniformizados três grupos, de acordo com normatização do Surveillance, Epidemiology, and End Results Program (SEER): localizado (estadios I, IA, IB e IC), regional (estadios II, IIA, IIB, IIC, IIIA) e distante (estadios III, IIIB, IIIC e IV). No campo histológico, os pacientes 
foram agrupados da seguinte forma: seroso, mucinoso, endometrioide, células claras, epitelial sem especificação histológica, e carcinoma indiferenciado.

Não havia detalhes sobre o tipo de cirurgia ou característica e momento da quimioterapia. Tais variáveis foram dicotomizadas em "sim" ou "não".

Tempo de sobrevida foi calculado subtraindo a data da última avaliação de seguimento da data do diagnóstico. Os possíveis estados na última consulta de acompanhamento eram: 0 , se vivo; 1 , se falecido por câncer de ovário; 2 , se falecido de outra causa.

Os hospitais nos quais os pacientes foram tratados foram classificados em alto volume cirúrgico se a mediana de número de casos operados por ano por câncer epitelial de ovário fosse 20 ou mais. Caso contrário, foram classificados como hospitais de baixo volume.

Adicionalmente, determinou-se quais instituições seriam classificadas como hospitais escola. O sistema do CNESNet do Ministério da Saúde registra um total de 202 hospitais escola no Brasil. A portaria interministerial número 2302 dos Ministérios da Saúde e da Educação lista os 202 hospitais escola do país. Usamos esta lista para identificar, dentre os hospitais presentes nos dados disponíveis, quais eram hospitais escola. Todos os demais serviços foram classificados como hospitais regulares.

\section{Banco de dados e análise estatística}

Manipulação de dados e análise estatística foram realizados utilizando o software R versão 3.4.1 (30/06/2017).

Para análise de sobrevida, os casos foram censurados a direita em dez anos de acompanhamento. O estimador de Kaplan-Meyer foi usado para estimar a sobrevida global. Para avaliar a influência das características dos hospitais, como sendo de alto volume cirúrgico e de ensino, na sobrevida dos pacientes, utilizamos o modelo de riscos proporcionais de Cox. 
ANEXO 2. Aprovação do Comitê de Ética.

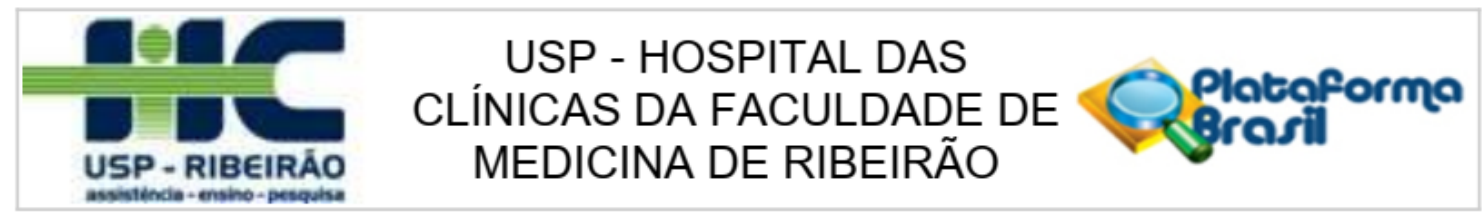

\section{PARECER CONSUBSTANCIADO DO CEP}

\section{DADOS DO PROJETO DE PESQUISA}

Título da Pesquisa: Evolução da sobrevida em mulheres com tumores ginecológicos e da mama no estado de São Paulo

Pesquisador: Francisco José Candido dos Reis

Área Temática:

Versão: 1

CAAE: 66233317.5 .0000 .5440

Instituição Proponente: Hospital das Clínicas da Faculdade de Medicina de Ribeirão Preto da USP -

Patrocinador Principal: Financiamento Próprio

\section{DADOS DO PARECER}

Número do Parecer: 1.996.142

\section{Apresentação do Projeto:}

Trata-se de um estudo ecológico com análise da evolução da sobrevida de mulheres com tumores ginecológicos e da mama.

\section{Objetivo da Pesquisa:}

Objetivo Primário: Caracterizar a evolução da sobrevida global nos cânceres ginecológicos e da mama no Estado de São Paulo.

Objetivo Secundário:

Avaliar a evolução da sobrevida nos cânceres ginecológicos e da mama por estádio.

Avaliar a evolução da sobrevida nos cânceres ginecológicos e da mama por tipo histológico específico.

Análise da evolução comparada da sobrevida segundo o sítio primário da neoplasia (mama, colo, corpo uterino e ovários).

\section{Avaliação dos Riscos e Benefícios:}

Riscos: Esta pesquisa não acarretará exposição dos pacientes a quaisquer riscos, pois se trata de estudo envolvendo coleta de informações clínicas existentes no Registro Hospitalar de Câncer do Estado de São Paulo.

Benefícios: Ressalta-se que não haverá intervenção direta ao paciente, assim como benefícios

Endereço: CAMPUS UNIVERSITÁRIO

Bairro: MONTE ALEGRE CEP: $14.048-900$

UF: SP Município: RIBEIRAO PRETO

Telefone: (16)3602-2228 Fax: (16)3633-1144_E-mail: cep@hcrp.usp.br 


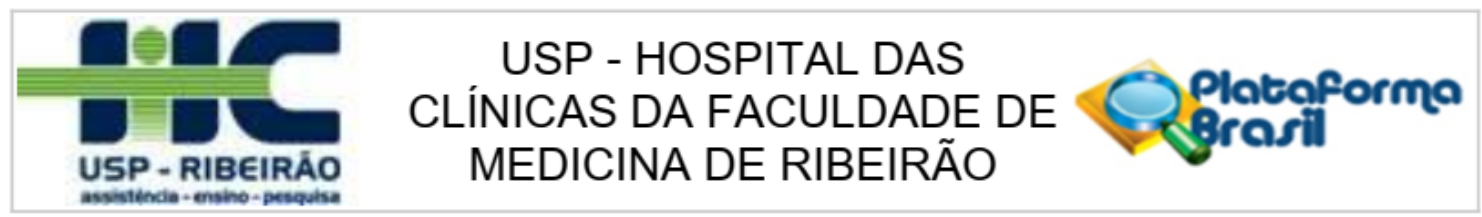

Continuação do Parecer: 1.996.142

extras como remuneração para os sujeitos participantes. Os resultados poderão contribuir para o entendimento da evolução e prognóstico dos cânceres ginecológicos e da mama, sendo estes divulgados apenas em revistas científicas, respeitando-se o sigilo da identidade dos pacientes envolvidos.

\section{Comentários e Considerações sobre a Pesquisa:}

Os dados demográficos, ano de diagnóstico, dados relativos à localização do tumor primário, tipo histológico do tumor, estádio, tipo de tratamento e tempo de sobrevida serão obtidos junto à Fundação Oncocentro de São Paulo (FOSP). Os hospitais componentes da Rede de Atenção Oncológica do estado de São Paulo são obrigados por lei a manter um Registro Hospitalar de Câncer e enviar os dados para a FOSP. A FOSP coordena os Registros Hospitalares de Câncer no estado e processa os dados coletados (RHC/FOSP). O RHC/FOSP tem dados disponíveis a partir do ano 2000.

\section{Considerações sobre os Termos de apresentação obrigatória:}

Documentos devidamente apresentados. Solicita a dispensa de aplicação do Termo de Consentimento Livre e Esclarecido. A dispensa do uso de TCLE se fundamenta: i) por ser um estudo observacional, analítico ou descritivo retrospectivo, que empregará apenas informações de sistemas de informação institucionais e/ou demais fontes de dados sem previsão de utilização de material biológico; ii) porque todos os dados serão manejados e analisados de forma anônima, sem identificação nominal dos participantes de pesquisa; iii) porque os resultados decorrentes do estudo serão apresentados de forma agregada, não permitindo a identificação individual dos participantes, e iv) porque se trata de um estudo não intervencionista (sem intervenções clínicas) e sem alterações/influências na rotina/tratamento do participante de pesquisa, e consequentemente sem adição de riscos ou prejuízos ao bem-estar dos mesmos. O investigador principal e demais colaboradores envolvidos no estudo acima se comprometem, individual e coletivamente, a utilizar os dados provenientes deste, apenas para os fins descritos e a cumprir todas as diretrizes e normas regulamentadoras descritas na Res. CNS N ${ }^{\circ} 466 / 12$, e suas complementares, no que diz respeito ao sigilo e confidencialidade dos dados coletados.

\section{Recomendações:}

Não se aplica.

\section{Conclusões ou Pendências e Lista de Inadequações:}

Diante do exposto e à luz da Resolução CNS 466/2012, o projeto de pesquisa, assim como a

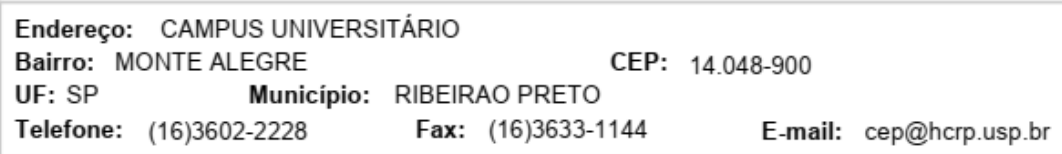




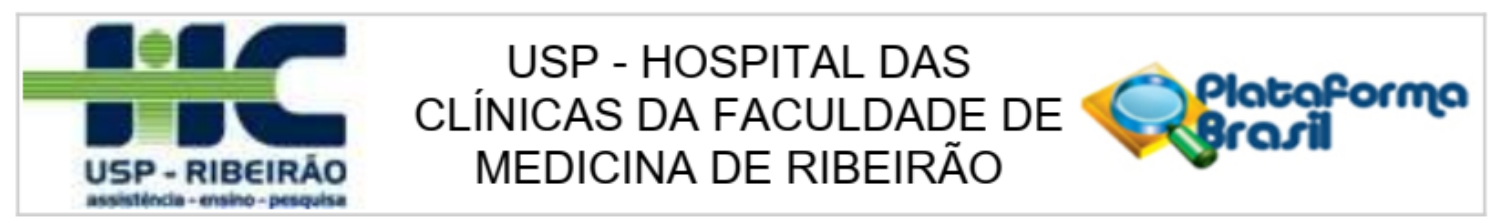

Continuação do Parecer: 1.996.142

extras como remuneração para os sujeitos participantes. Os resultados poderão contribuir para o entendimento da evolução e prognóstico dos cânceres ginecológicos e da mama, sendo estes divulgados apenas em revistas científicas, respeitando-se o sigilo da identidade dos pacientes envolvidos.

\section{Comentários e Considerações sobre a Pesquisa:}

Os dados demográficos, ano de diagnóstico, dados relativos à localização do tumor primário, tipo histológico do tumor, estádio, tipo de tratamento e tempo de sobrevida serão obtidos junto à Fundação Oncocentro de São Paulo (FOSP). Os hospitais componentes da Rede de Atenção Oncológica do estado de São Paulo são obrigados por lei a manter um Registro Hospitalar de Câncer e enviar os dados para a FOSP. A FOSP coordena os Registros Hospitalares de Câncer no estado e processa os dados coletados (RHC/FOSP). O RHC/FOSP tem dados disponíveis a partir do ano 2000.

\section{Considerações sobre os Termos de apresentação obrigatória:}

Documentos devidamente apresentados. Solicita a dispensa de aplicação do Termo de Consentimento Livre e Esclarecido. A dispensa do uso de TCLE se fundamenta: i) por ser um estudo observacional, analitico ou descritivo retrospectivo, que empregará apenas informações de sistemas de informação institucionais e/ou demais fontes de dados sem previsão de utilização de material biológico; ii) porque todos os dados serão manejados e analisados de forma anônima, sem identificação nominal dos participantes de pesquisa; iii) porque os resultados decorrentes do estudo serão apresentados de forma agregada, não

permitindo a identificação individual dos participantes, e iv) porque se trata de um estudo não intervencionista (sem intervenções clínicas) e sem alterações/influências na rotina/tratamento do participante de pesquisa, e consequentemente sem adição de riscos ou prejuízos ao bem-estar dos mesmos. O investigador principal e demais colaboradores envolvidos no estudo acima se comprometem, individual e coletivamente, a utilizar os dados provenientes deste, apenas para os fins descritos e a cumprir todas as diretrizes e normas regulamentadoras descritas na Res. CNS No 466/12, e suas complementares, no que diz respeito ao sigilo e confidencialidade dos dados coletados.

\section{Recomendações:}

Não se aplica.

Conclusões ou Pendências e Lista de Inadequações:

Diante do exposto e à luz da Resolução CNS 466/2012, o projeto de pesquisa, assim como a

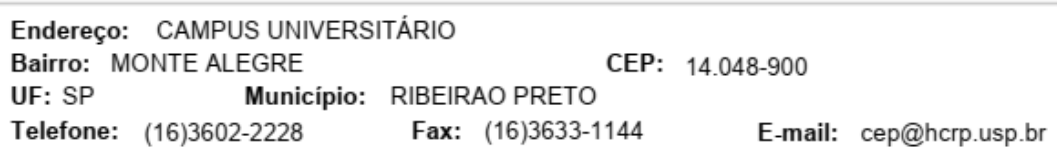




\section{USP - HOSPITAL DAS
$\begin{gathered}\text { CLINICAS DA FACULDADE DE Platoforma } \\ \text { MEDICINA DE RIBEIRÃO }\end{gathered}$}

Continuação do Parecer: 1.996.142

solicitação de dispensa de aplicação do Termo de Consentimento Livre e Esclarecido, podem ser enquadrados na categoria APROVADO.

\section{Considerações Finais a critério do CEP:}

Projeto Aprovado: Tendo em vista a legislação vigente, devem ser encaminhados ao CEP, relatórios parciais anuais referentes ao andamento da pesquisa e relatório final ao término do trabalho. Qualquer modificação do projeto original deve ser apresentada a este CEP em nova versão, de forma objetiva e com justificativas, para nova apreciação.

Este parecer foi elaborado baseado nos documentos abaixo relacionados:

\begin{tabular}{|c|c|c|c|c|}
\hline Tipo Documento & Arquivo & Postagem & Autor & Situação \\
\hline $\begin{array}{l}\text { Informações Básicas } \\
\text { do Projeto }\end{array}$ & $\begin{array}{l}\text { PB_INFORMAÇŐES_BÁSICAS_DO_P } \\
\text { ROJETO 870253.pdf }\end{array}$ & $\begin{array}{c}27 / 03 / 2017 \\
08: 58: 22 \\
\end{array}$ & & Aceito \\
\hline $\begin{array}{l}\text { TCLE / Termos de } \\
\text { Assentimento / } \\
\text { Justificativa de } \\
\text { Ausência }\end{array}$ & BrGyn_FOSP_UPC.pdf & $\begin{array}{c}27 / 03 / 2017 \\
08: 57: 24\end{array}$ & \begin{tabular}{|l} 
Francisco José \\
Candido dos Reis
\end{tabular} & Aceito \\
\hline $\begin{array}{l}\text { TCLE / Termos de } \\
\text { Assentimento / } \\
\text { Justificativa de } \\
\text { Ausência }\end{array}$ & BrGyn_FOSP_DGO.pdf & $\begin{array}{l}19 / 03 / 2017 \\
17: 29: 06\end{array}$ & $\begin{array}{l}\text { Francisco José } \\
\text { Candido dos Reis }\end{array}$ & Aceito \\
\hline $\begin{array}{l}\text { Projeto Detalhado / } \\
\text { Brochura } \\
\text { Investigador }\end{array}$ & BrGyn_FOSP_FranciscoReis.pdf & $\begin{array}{c}19 / 03 / 2017 \\
17: 28: 29\end{array}$ & $\begin{array}{l}\text { Francisco José } \\
\text { Candido dos Reis }\end{array}$ & Aceito \\
\hline Folha de Rosto & BrGyn_FOSP_FR.pdf & $\begin{array}{c}19 / 03 / 2017 \\
17: 26: 49\end{array}$ & $\begin{array}{l}\text { Francisco José } \\
\text { Candido dos Reis }\end{array}$ & Aceito \\
\hline $\begin{array}{l}\text { TCLE / Termos de } \\
\text { Assentimento / } \\
\text { Justificativa de } \\
\text { Ausência }\end{array}$ & BrGyn_Dispensa_de_Consentimento.pdf & $\begin{array}{c}16 / 03 / 2017 \\
10: 07: 14\end{array}$ & $\begin{array}{l}\text { Francisco José } \\
\text { Candido dos Reis }\end{array}$ & Aceito \\
\hline
\end{tabular}

\section{Situação do Parecer:}

Aprovado

\section{Necessita Apreciação da CONEP:}

Não

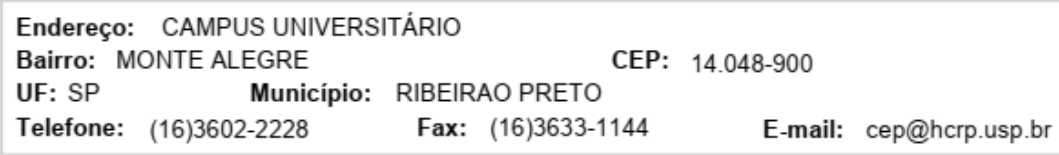




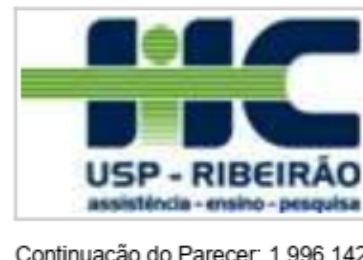

\section{USP - HOSPITAL DAS \\ CLÍNICAS DA FACULDADE DE MEDICINA DE RIBEIRÃO

Continuação do Parecer: 1.996.142

RIBEIRAO PRETO, 03 de Abril de 2017

Assinado por:

MARCIA GUIMARÃES VILLANOVA

(Coordenador) 